\title{
PERLAWANAN SENYAP TERHADAP SISTEM PERNIKAHAN ADAT MELALUI SASTRA TULIS: NOVEL BELIS IMAMAT, KARYA INYO SORO
}

Siti Rodliyah

Universitas Muhammadiyah Kupang, rodliyahs@rocketmail.com

\begin{abstract}
Belis Imamat (BI), sebuah novel karya Inyo Soro menceritakan tentang perjalanan hidup seorang calon pastor (Iting), bercita-cita menentang tirani belis (mas kawin) yang dirasa menjadi sumber berbagai masalah sosial sepanjang generasi. Pokok bahasan dalam penelitian ini mengangkat fenomena sosialbudaya yang dikemas penulis melalui sebuah novel, pandangan dunia penulis, dan nilai pendidikan yang tercermin dalam novel tersebut. Teknik pengumpulan data dalam penelitian ini menggunakan analisis dokumen, mulai dari tahap membaca, pencatatan dan kemudian analisis dokumen. Pandangan Inyo Soro tentang keberadaan belis dalam adat-istiadat masyarakat Nusa Tenggara Timur sebagaimana diceriterakan dalam novel belisImamat mengungkapkan bahwa belis memang sebuah tradisi yang mencerminkan pernikahan tradisional yang sangat memberatkan, bahkan lebih dari itu, belis sering mengikis nilai-nilai cinta dan kemanusiaan. Disamping menjadi syarat sahnya sebuah hubungan perkawinan, tradisi yang kuat dan tak terelakkan anggota masyarakat yang menjunjung tinggi belis menunjukkan pandangan alternatif seorang penulis terhadap esensi belis dengan sesuatu yang bernilai lebih tinggi daripada materi yakni gelar kehormatan Imamat. Pentahbisan gelar imamat merupakan pengganti bagi belis orang tua yang pernah terhutang, yang pada dasarnya sebagai refleksi hakikat belis itu sendiri.
\end{abstract}

Keywords: Belis Imamat; novel; adat; masyarakat

\section{PENDAHULUAN}

Karya sastra bisa mencerminkan pikiran, kehidupan dan tradisi dalam masyarakat setempat. Menurut Wellek dan Warren (1989: 109), pembaca sastra mungkin bisa melihat sesuatu yang terjadi di wilayah tertentu,sehingga, buah 


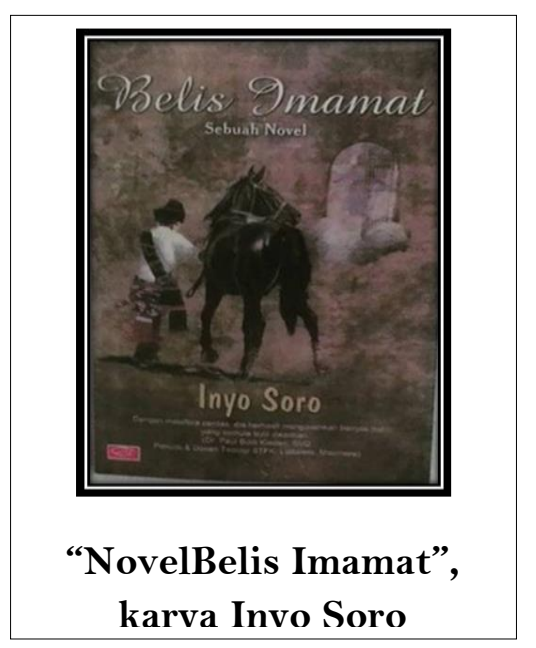

menghubungkan kehidupan pikir penulis baik secara langsung atau taklangsung dipengaruhi oleh lingkungannya sendiri dan secara otomatis memang memiliki efek tertentu terhadap karya sastra yang dihasilkan. Karya sastra yang terpengaruh oleh lingkungan sosialnya terjadi karena hal-hal yang diangkat merupakan bagian dari masyarakat itu juga (Wellek \& Warren, 1989: 112).

Novel adalah simbol seni baru yang dan pengalaman faktual sosio-kultural para penulisnya, sehingga apapun yang dijelaskan dalam novel cenderung bersifat realistis dan masuk akal. Kehidupan yang digambarkan bukan hanya kebesaran dan kekuatan karakter (terhadap tokoh yang ingin diangkat), tapi juga cacat dan kekurangannya. Lebih jauh lagi, dia menyatakan bahwa sebuah novel seyogyanya bukan hanya alat hiburan, namun juga sebagai bentuk seni yang memelajari dan melihat aspek nilai-nilai sosial yang tinggi dalam kehidupan bermasyarakat, mengarahkan pembaca untuk bertindak dan berpikir lebih bijaksana (Waluyo, 2002). Disamping itu, Abrams (dalam Nurgiyantoro, 1994) mengungkap bahwa novel berasal dari kata dalam bahasa Italia novella (bahasa Jerman: novelle). Secara harafiah novella berarti hal baru dan kemudian diterjemahkan sebagai "cerita pendek dalam bentuk prosa". Saat ini, gagasan novella atau novelle mencerminkan arti yang sama dengan novelet istilah dalam Bahasa Indonesia (bahasa Inggris: novellette) yang berarti sebuah proxy karya fiksi yang secara substansial tidak terlalu panjang atau tidak terlalu pendek. Karya sastra yang disebut novellette adalah karya yang lebih pendek dari novel tapi lebih panjang daripada cerita pendek; namun bisa termasuk keduanya.

http://journal.unesa.ac.id/index.php/paramasastra | $\mathbf{5 7}$ 
Fenomena yang diangkat oleh seorang penulis dalam karya sastranya mencakup hampir semua aspek kehidupan yang dialami pribadi dan masyarakatnya. Munculnya novel sebagai bentuk karya sastra juga mengguncang kesadaran bahwa di tengah pertunjukan lisan dan kesenian, sastra tulis adalah suatu fakta yang harus ada. Sebagai pemerhati sastra tentunya kita juga sedikit banyak memahami tentang bagaimana kehidupan sehari-hari merupakan inspirasi tak terduga dalam mengukir serangkaian cerita unik dan dapat menyentuh khalayak pembacanya. Eko Sugiarto (2007) menulis sebuah ulasan berjudul "Melayu di Mata Soeman Hs kritik terhadap adat melalui sebuah kritik baru terhadap adat melalui sebuah novel", yang merupakan studi analitis tentang novel Soeman HS "Kasih Tak Terlarai". Eko sengaja mengulas novel ini melalui teori mitos Levi-Strauss. Melalui penjelasan mitologis, ia mencoba membangun argumennya tentang 'misi perlawanan' yang dibawa oleh Soeman HS dalam novelnya. Anas al Lubab dalam artikelnya Ketika Pernikahan Dikuasai Adat dalam "Memang Jodoh" mengulas sebuah novel karya Marah Rusli, seorang novelis legendaris dimana salah satu karya fenomenalnya berjudul Siti Nurbaya dikenang dalam sejarah sastra Indonesia. Sebagai seorang penulis novel Sitti Nurbaya, nampaknya Marah selalu merasa gugup dengan realitas sosial ketundukkan masyarakat pada tradisi yang membelakangkan dijunjung tinggi. Melalui sisi intelektualitasnya, pengarang memberontak melawan pernikahan adat di Padang. Jika melalui karyanya Siti Nurbaya, Marah Rusli memotret budaya atau kebiasaan tanah airnya tentang bagaimana kekuasaan-harta dan takhta - secara harfiah telah mengambil hak wanita menjadikannya sebagai objek yang harus "dijual" untuk melunasi hutang orang tuanya. Penulis rupanya belum puas mempertahankan posisi pemberontakannya dalam mengkritik kehidupan adat yang dianggap membatasi pembinaan intelektual dan hak asasi manusia. Berdasarkan kasus tersebut, ia merasa wajib menulis sebuah novel berjudul 
"Memang Jodoh" yang terinspirasi dari pengalaman pernikahannya dengan istrinya.

Terlepas dari karya dan ulasan sebelumnya, pemilihan novel Inyo Soro "Belis Imamat" sebagai objek penelitian ini didasarkan pada alasan bahwa novel tersebut mengungkapkan tentang kehidupan religius, dan masalah sosial konsekuensi adatdan budaya setempat yang memengaruhi masyarakat Sumba, dan sebagian besar di Nusa Tenggara Timur. Inyo Soro berhasil mengungkapkan sisi kehidupan belis sebagai suatu hal yang indah, sebagai syarat mutlak dan penghargaan tinggi terhadap calon mempelai yang harus terpenuhi sebelum digelarnya suatu pernikah, namun tidak hanya dari segi positif, akan tetapi juga negatifnya. Novel Belis Imamat karya Inyo Soro, sebagian besar epilog ceritanya merefleksikan sosio-kultural aspek-aspek kehidupan masyarakat Nusa Tenggara Timur. Disamping itu, artikel ini membahas pandangan dunia penulis mengenai sistem perkawinan yang menerapkan belis, merupakan suatu kenyataan sosialbudaya yang dihadapi penulis pada saat itu, disamping nilai-nilai pendidikan yang ditanamkan. Mempertimbangkan pentingnya nilai pendidikan sebagai salah satu permasalahan yang paling disorot dalam novel ini, terlepas dari karya sastra apapun harus mengandung nilai kehidupan yang dengan sengaja mampu mendidik para pembacanya. Kajian nilai pendidikan memang merupakan nilai plus yang layak diserap oleh para pembaca.

\section{Metode}

Metode kualitatif menjadi paradigma dasar dan desain penelitian ini. Metode penelitian kualitatif menghasilkan data deskriptif berbentuk narasi tertulis atau lisan dari aspek yang dapat diamati untuk memungkinkan penulis menggambarkan suatu individu, keadaan, gejala dari kelompok tertentu (Moleong, 2008). Metode deskriptif dapat diartikan sebagai prosedur pemecahan 
masalah dengan menggambarkan keadaan subjek atau objek saat ini (seseorang, institusi, masyarakat, dll) berdasarkan fakta yang muncul atau seperti apa dan bagaimana (Hadari Nawawi dalam Siswantoro, 2005). Penulis menjelaskan secara kualitatif mengenai permasalahan yang diangkat dalam penelitian ini. Metode etnografi kritis diterapkan dalam penelitian ini sebagai metode yang bertujuan untuk mengeksplorasi beberapa faktor termanifestasi (tersembunyi) seperti bagaimana suatu daya bekerja atau kekuatan hegemoni yang memengaruhi suatu masyarakat tertentu, dan berusaha membuka agenda tersembunyi di balik kenyataan yang berlangsung. Antropolog berpendapat bahwa etnografi bukan sekadar karya tulis, namun juga harus mematuhi peraturan 'ilmiah'. Jika 'plot' dan struktur menjadi prinsip standar penulisan novel, objektivitas pembenaran empiris menjadi tulang punggung yang menentukan apakah menulis bisa dikategorikan sebagai kegiatan 'etnografis'.

Analisis plot terkait dengan "move" atau alur, dan "narrative program"atau program naratif (Czarniawska 2012). Kebanyakan cerita dalam novel atau karya sastra lain berisi lebih dari satu alur, atau beberapa program naratif yang bersaing dan saling terhubung membentuk interpretasi baru. Namun, yang paling banyak disebut analisis plot berasal dari teoretikus sastra BulgariaPrancis, Tzvetan Todorov pada tahun 1977 yang menjelaskan bahwa analisis plot yang paling mendasar adalah memuat tahapan yang berkaitan satu sama lain narasi ideal yang stabil dihasilkan oleh suatu daya. Selanjutnya atmosfer berubah menjadi disekuilibrium, buah akibat dari kemunculan daya baru. Hal ini sebagaimana yang dikemukakan Czarniawska (2012: 758), bahwa:

The minimal complete plot consists in the passage from one equilibrium to another. An "ideal" narrative begins with a stable situation which is disturbed by some power or force. There results a state of disequilibrium; by the action or a force directed in the opposite direction, the equilibrium is reestablished; the second equilibrium is similar to the first, but the two are never identical. 
Dalam hal ini, kombinasi plot biasanya dicapai melalui dua strategi: pertama, menghubungkan (koordinasi) adalah menambahkan plot sederhana satu sama lain, sehingga dapat bersesuaian. Kedua, melalui sistem embedding (subordinasi) adalah menceritakan sebuah plot yang merupakan bagian dari plot lain (Czarniawska 2012).

\section{HASIL DAN PEMBAHASAN}

\section{Belis Imamat (BI)}

Belis Imamat (BI) adalah sebuah novel buah karya seorang penulis NTT, Inyo Soro, yang terbit akhir tahun 2010an. Ia adalah alumnus Sekolah Teologi Katolik St. Paulus Ledalero di Maumere, Nusa Tenggara Timur. BI bercerita tentang perjalanan hidup seorang calon pastor (Iting) dari Sekolah Tinggi Seminari sampai pada akhir cerita petahbisannya. Berbeda dengan kisah kehidupan saleh Santri, seperti yang diceritakan dalam beberapa novel Islami oleh Habiburrahman El Shirazy, misalnya dalam novel 'Ayat-ayat Cinta' dan 'Ketika Cinta Bertasbih' dst. Inyo Soro dengan gaya polos, cerdas, kritis dan mengesankan, menampilkan kehidupan anak laki-laki muda. Kenakalan dan kejenakaan mereka yang meskipun hampir sama seperti pribadi anak-anak muda pada umumnya.

Inyo Soro tumbuh di tengah situasi akademis seminari yang royal terhadap perlawanan kroniknya. Buletin Sastra Sandal jepit, sebuah forum diskusi Republik Sarung dan Teater Aletheia adalah suasana di sekitar penulis yang telah berhasil berkontribusi dalam membangun ide-ide kreatif cerita barunya. Yang dimaksud dengan cerita kusut ini mungkin segera didasarkan pada fakta historis yang valid, dan mungkin masih dipertahankan hingga sekarang di Ledalero, sebagai latar belakang novel ini. Terlepas dari mimetik terhadap pengalaman masa lalunya, 
otonomi semantik teks novel ini dalam model bacaan saya, menawarkan makna simbolis yang tidak murahan. Seperti Santo Paulus yang menyarungkan pedang dan menggunakan pena sebagai senjata, terlebih bagi Inyo Soro, menulis adalah senjata untuk memperjuangkan nilai-nilai kemanusiaan dan merangkul kebenaran.

Iting (tokoh yang diterangkan sebagai 'Aku') adalah tipe orang serius yang bercita-cita menjadi imam Katolik seminari yang tinggal di dalam sebuah asrama ekstra ketat. Aturan keseharian siswa seminari persis sebagaimana yang digambarkan Michel Foucault, yakni sebagai mandor kecil yang mewarisi peran panoptikon, penguntit di penjara yang senantiasa menyebarkan teror. Semua ini dimaksudkan demi menyiapkan kandidat pastoral yang mampu diandalkan.Meskipun demikian keadaannya, Iting telah berhasil menjalankan kehidupan asrama yang diproyeksikan menjadi praktik imamat di masyarakatnya kedepan.

Meskipun kehidupan seorang calon pendeta muda tampak agak terisolasi, suatu tantangan berupa ujian mungkin datang dari mana saja. Dialog Iting dengan teman pendampingnya, zetof zonder(hlm. 9-12) adalah contoh serangan kritis yang secara langsung menembus inti kehidupan monastik. Bagi beberapa orang, pilihan untuk menjadi imamat terlalu tidak masuk akal, namun tidak jarang kemiskinan, kemurnian dan ketaatan ideal yang segera menjadi ironi di luar ibadah Katolik. Tantangan umum yang menimpa calon pendeta yang diceriterakan Inyo Soro merupakan produk tulis yang agaknya mencerminkan selera humor. Suatu hari, Iting bertemu Bintang yang jatuh, makhluk yang berhasil membuat darah Iting mengalir begitu deras serta menggejolak. Inilah cerita cinta seorang calon pendeta. Jika kisah cinta Bintang jatuh, yang diceritakan mengenai perasaan Iting yang tak bergayut lantaran sang gadis tak juga menerima cintanya.

Pada sisi lain cerita BI menceritakan kisah pilu percintaan antara Pit dan Ros, yang tiada lain adalah kedua orang tua Iting, perihal perkawinan antara akar rumput Flores dengan gadis terhormat di Sumba yang hamil di luar pernikahan. 
Siti Rodliyah, Perlawanan Senyap Terhadap... (hlm. 246-259)

Pit dan Ros akhirnya berhasil lolos ke kota Kupang karena Pit sebagai pengantin laki-lakinya tidak mampu membayar belis. Dalam kasus ini, belenggu belis sempat meredam cinta dan hati sepasang kekasih tersebut meregang rindu dalam dendam. Novel ini selain bersifat deskriptif sosio-kultural, juga cukup optimis bercita-cita sebagai solusi yang lebih efektif untuk meringankan tirani belis yang menjadi sumber berbagai masalah sosial di kalangan akar rumput. Timbulnya permasalahan sosial ini, seseorang tidak dapat mengandalkan apa yang Inyo Soro implikasikan dalam tulisannya sebagai 'faktor X'.

\section{Novel Belis Imamat:}

\section{Ekspresi Penulis Terhadap Kondisi Sosial: Sebuah Kritikan Halus}

Novel ini menceritakan latar belakang kehidupan calon pastor di Sekolah Tinggi Filsafat Katolik di Ledalero. Pahit-manisnya pengalaman 'Aku' digambarkan secara rinci dalam novel ini. Salah satu hal menarik yaitu ketika sosok 'Aku' merasakan kontradiksi dirinya terhadap sistem adat setempat. Pengalaman ironis yang dirasa terutama pada saat memenuhi tugas sebagai penasihat dalam perkawinan, sementara sebagai pastor yang tidak pernah tahu atau bahkan tidak diperbolehkan menjalani suatu hubungan pernikahan.

..tapi segera aku sadari,membuat khotbah seperti nasehat mereka memang tak mudah. Apalagi untuk mengkhotbahkan pernikahan pasutri (pasangan suami istri) alias memberi kesaksian hidup tentang pernikahan yang padahal aku dan teman-temanku dinarahkan untuk tidak menikah. Sungguh sebuah kegelisahan yang salah huruf bisa dibaca sebagai Ironi (BI, hal.7)

Kekhawatiran yang menimpa sosok "Aku" dalam Novel BI bukan hanya karena peranannya sebagai calon imamat, namun juga pengalaman sebagai 
seorang anak yang terlahir dari kedua orang tua yang dipandang miring dalam masyarakatnya lantaran tidak mampu melangsungkan pernikahan d adat bermaharkan belis. Ayahnya adalah seorang pria dari keluarga sederhana bernama Pit, sedangkan ibunya bernama Rose, seorang gadis dari kalangan bangsawan bergelar Rambu. Di Sumba, masyarakat lokal masih lazim yang lainnya dengan pandangan stratifikasi sosial. Demikian pula bagi mereka yang bergelar Rambu berhak mendapatkan seorang laki-laki bangsawan pula yang bergelar Umbu, sebutan gelar terhormat untuk pria. Belis yang meskipun tidak dapat sepenuhnya didefinisikan sebagai mas kawin di Sumba memang dipatok dengan besaran biaya yang sangat tinggi apalagi jika gadis calon istri berstatus bangsawan, belis yang menjadi ketentuan bisa mencapai puluhan kerbau, kuda, emas dan gading. Belis seakan menjadi harga mati karena dianggap sebagai pengganti ASI. Hal ini tercermin dalam penggalan cerita dalam novel Belis Imamat:

Sebagai laki-laki Timur, kami diajari kalau melunasi belis merupakan kewajiban terhadap kaum keluarga wanita. Tidak melunasi belis sama artinya tidak menghargai wanita beserta kaum keluarganya (BI, hal.46)

Belis bagi orang timur memiliki nilai yang tinggi. Belis melambangkan penghargaan pria terhadap wanita. Belis merupakan penghargaan pada orang tua wanita yang telah mengasuh dan membesarkan wanita pinangan pria. Secara metaforis belis dianggap sebagai “balas air susu mama” (BI, hal.45)

Bagi masyarakat di Nusa Tenggara Timur, khususnya masyarakat Sumba, meluniasi belis merupakan manifestasi penghargaan tinggi laki-laki terhadap perempuan. Namun, penting untuk dicatat, mengenai cara dan usaha menjadikan belis sebagai kewajiban, pun sejatinya kehormatan laki-laki tidak akan terkurangi. Nilai-nilai sosial-pendidikan yang tercermin dalam novel Belis 
Imamat memposisikan belis sebagai bentuk apresiasi kepada pengantin wanita dan keluarganya yang dinilai memiliki peran besar dalam membesarkan calon istri sedari kecil hingga dewasa. Keberadaan belis seiring dengan fungsi dan makna sosial masyarakat NTT, khususnya masyarakat Sumba Timur adalah cerminan nilai-nilai sosial. Belis mencerminkan prestise dan harga diriwanita maupun pria; antara belis yang terbayar lunas ataupun tidak, belis menunjukkan norma sosial dan kemampuan ekonomi masing-masing keluarga. Nilai sosial belis memupuk kerja sama antar keluarga yang bersangkutan. Belis dalam pelunasannya sering melibatkan keluarga besar pihak pria maupun wanita. Menghormati wanita dan keluarga orang tua mereka adalah sebuah bentuk nilai sosial yang diajarkan dalam tradisi belis.

Karena itu suatu saat, kembalilah kesini. Antarkan belis buat keluarga Ros, biar kau di anggap lelaki terhormat. Belismu adalah hutangmu dan juga harga dirimu. Jangan rendahkan harga dirimu dengan tidak melunasinya (BI, hal.45)

Oleh sebab dihadapkan dengan permasalahan dalam membayarkan belis, orang tuaku, Pit dan Rose diusir dari kampung, keluarga dan masyarakat mereka di Sumba. Keduanya kemudian pergi ke Kupang, Ibu Kota Provinsi Nusa Tenggara Timur. Mereka menetap dan tinggal di Kupang, dan takut kembali ke Sumba hingga melahirkan dua anak, salah satunya adalah tokoh dalam cerita yakni 'Aku'.

Tokoh 'Aku' yang menjalankan peran kehidupan sebagai calon seorang Imamat, akhirnya menerima tugas terakhirnya yang berlangsung di Sumba, merupakan tempat kelahiran kedua orang tuanya, tempat tinggal kerabat dan keluarga besarnya. Kehadiran sosok Aku, sebagai calon Imamat dalam lingkaran kerabat di Sumba, perlahan tapi pasti melelehkan kedinginan hubungan dan 
isolasi yang terbangun antara dia, orang tuanya dan keluarga besarnya sebagai akibat dari memegangteguh adat pernikahan dengan belis. Pernikahan kedua orang tuanya di masa lalu yang dianggap tidak sah karena ketaksanggupan membayar belis. Keduanya sempat terpisah mulai tidak saling mengenal hingga tidak diperkenankan berjumpa bertahun lamanya.

Pada akhirnya sosok 'Aku' dapat menyatukan kembali keluarganya yang tercerai-berai, ayah dan ibunya serta keluarga besar keduanya pada saat pentahbisan sosok 'Aku' sebagai pastor. Kedua keluarga bisa berkumpul bersama dalam acara tersebut. Permasalahan belis yang selama ini sempat membelenggu diantara keluarga orang tuanya berakhir dengan pernyataan mengharukan dari sosok 'Aku', bahwa pentahbisan gelar Imamat sebagai pastor diperuntukkan atas belissang ayah kepada ibunyayang terhutang. Cerita novel ini berakhir disini.

Di depan nenekku, di depan kaum keluarga yang pernah menolak ayah-ibuku, kupersembahkan iamamatku sebagai belis bagi mereka. Belisku adalah belis ayahku. Belis bagi keluarga ibuku. Meski bukan dengan ternak.Bukan dengan gading.Bukan dengan perhiasan emas, intan dan berlian. Ku persembahkan sesuatu yang sederhana untuk mereka yang mana kesederhanaan itu ternyata amat berharga di mata nenek, tante,kaum kerabatku, ayah dan bundaku. Ya,imamat tak lain tak bukan adalah belis kehidupan. Belisku untuk nilai kehidupan yang terlampau luhur (BI, hal.246).

Kegiatan seminari dan kampus merupakan realitas yang boleh dibilang tidak masuk akal bagi Inyo Soro. Novel yang diilhami dari cerita pribadi kehidupan seorang pemuda calon pastor yang penuh idealisme kebebasan berkreasi yang berapi-api, kebebasan berpendapat serta mengemukakan gagasan sebagai kritikan. Gagasan tentang kebebasan, terutama pemikiran bebas tanpa ada batasan, dan naluri kompetitif dalam mencari kebenaran merupakan nilai- 
nilai pendidikan yang ingin disampaikan penulis. Setelah Bab prolog, pembaca bias dipastikan akan bertanya-tanya, kira-kira apa yang menyebabkan seorang penulis menggunakan gaya bahasa orang pertama tunggal 'Aku' mempersembahkan gelar kependetaan dirinya sebagai ganti objek material belis / mas kawin kedua orang tuanya yang terhutang? Di lain sisi menjalani pendidikan dengan dua variasi orientasi berupa tuntutan yang terlahir dari kesadaran pribadi dan umum, dan tuntutan keluarga, serta tuntutan 'masyarakat' religius. Hal tersebut menjadi permakluman bagi analis novel untuk melacak kumpulan cerita tentang lingkungan para siswa tempaan Sekolah Tinggi Filsafat Katolik yang menginspirasi 'tragedi' epilog dalam novel BI.

\section{Resistensi terhadap Sistem Adat yang Mengekang}

Sebelum menulis bisa dijadikan sebagai senjata, seseorang harus terlebih dahulu berjuang untuk memelajarinya. Seperti saat pertama mengayuh sepeda, orang pasti berusaha menjaga keseimbangan tubuhnya. Tidak mengherankan, Inyo Soro mengungkapkan buah pikir kreatifnya kedalam 5 bab dalam novelnya untuk bercerita tentang pengalaman menulis. Di beberapa bagian, tulisan itu merupakan pengalaman yang unik, dan pada sosok Iting kita dapat memahami pengalaman Inyo Soro nampak selalu mendebarkan. Pengalaman menyiapkan khotbah untuk pasangan yang merayakan pernikahan perak dsb (BI, hlm.3). Tugas para dosen untuk mengabstraksikan gagasan para filsuf dari era Plato sampai era Postmodern seperti saat ini kedalam halaman HVS kemudian menjadikannya sebagai laporan akhir akademi pastoral (halaman 87-90); tugas menyiapkan naskah teater (hlm. 106); pengalaman menulis puisi berdasarkan pengalaman jatuh cinta (hlm. 127-128); menulis tesis (hlm. 186-189); yang tidak lagi implisit dalam teks novel tersebut adalah kesuksesan Iting, apakah ini sebentuk personifikasi dari penulis sendiri (?), yang mengekspresikan 
pengalaman fisik dan batin seorang penulis. Pengulangan pengalaman menulis di beberapa bagian novel selalu diapit oleh refrain yang sama.

Sesampainya di halaman terakhir novel BI ini, sebuah pertanyaan mungkin saja bisa diajukan; apakah komitmen Iting dan Bintang akan menjadikannya sebagai saudara perempuannya pada akhirnya? Sedangkan perihal percintaan, sebagaimana ditekankan Inyo Soro, "... Cinta adalah ihwal perubahan naluriah pemicu kedekatan setiap pria dan wanita." (hlm 25). Meskipun pada hakikatnya dalam pandangan calon pastor, kedekatan antara pria dan wanita mungkin saja ditafsiri sebagai bara api. Hal ini pastinya akan menuai efek ganda saat kedekatan antara laki-laki dan melibatkan kehidupan seorang calon pendeta, orang yang hanya berurusan dengan permasalahan agama dan telah berjanji untuk tidak menikah seumur hidupnya. Berakhirnya cerita Iting pada BI ini menyimpulkan pengalaman batin penulis yang menggunakan novel sebagai sastra lokal tanah air menjadi cerita tersendiri apakah akan ditanggapi khalayak sastra sebagai otokritik bagi adat setempat atau hanya hiburan edukatif yang hanya bisa diambil pelajaran bagi sebagian? Ataukah novel terdahulu menginspirasi lahirnya BI ? Pengamatan lebih lanjut melalui literatur komparatif perlu membahas komposisi cerita ini.

\section{Analisis Struktural Novel Belis Imamat}

Pandangan Inyo Soro mengenai ihwal belis yang menjadi bagian adat masyarakat Nusa Tenggara Timur yang diungkapkannya dalam BI adalah pandangan terhadap esensi belis sebagai sebuah tradisi pernikahan yang tak dapat disangkali, bahkan lebih dari itu, belis sering mengikis nilai cinta dan kemanusiaan yang melandasi tujuan pernikahan. Tradisi belis yang kuat dan tak terelakkan dijunjung tinggi oleh masyarakat, membuat penulis berpikir panjang kemudian menyampaikan gagasannya melalui coretan pena berbentuk kisah dalam novel, tidak lain diproyeksikan sebagai pandangan alternatif terhadap belis 
sebagai beban yang semestinya dapat digantikan oleh sesuatu yang bernilai lebih tinggi daripada materi untuk membelis seorang mempelai wanita, yakni nilainilai agama. Pentahbisan gelar Imamat sebagai gelar kehormatan tertinggi, merupakan pengganti bagi materi belis, yang sejatinya menjadi kritik terhadap esensi belis itu sendiri. Ada kemungkinan bahwa ini mengarah pada opini terhadap pemegang tradisi masyarakat yang peduli melestarikan belis menjadikan agama sebagai perantara kebuntuan tradisi adat. Analisis struktural berikut ini berusaha memerikan kondisi sosial budaya melalui kisah yang dikemas dalam novel bertajuk Belis Imamat.

Latar belakang atau background didasarkan pada kehidupan adat dan kepercayaan Marappu, belis telah terjaga keberadaannya secara turun temurun oleh nenek moyang orang Sumba Timur. Kebiasaan yang terkandung dalam novel BI ini adalah tradisi dalam pernikahan adat, yakni penyerahan belis sebagai mahar perkawinan. Tradisi ini dianggap sebagai penentu sah tidaknya sebuah pernikahan dalam pandangan adat, dan sebagai penentu bagi status perkawinan dari keturunan yang dihasilkan nantinya. Jumlah kadar belis tergantung pada status gadis, biasanya jumlah barang yang ditentukan tidak boleh kurang dari jumlah yang pernah diterima oleh ibu pada pernikahannya dahulu, setidaknya jumlah belis anak gadis tersebut harus sama dengan belis yang diterima si ibu.Belis dapat dipandang sebagai sebuah aturan adat dalam pernikahan yang harus dibayarkan atau terbayar dengan konsekuensi tertentu. Artinya, jika berhutang, pria harus ikut dalam segala aktifitas atau kegiatan keluarga si gafis sampai belis yang dibebankan padanya tuntas terbayarkan. Bagi masyarakat Sumba Timur seperti yang dijelaskan dalam novel BI, jumlah ternak menjadi bentuk pembayaran rasional dan setimpal dalam melunasi mahar pernikahan yang disebut belis. Pekerjaan/occupations; masyarakat Sumba Timur menjalani kehidupan utamanya melalui pekerjaan lapangan bersifat tradisional. Usaha- 
usaha yang banyak dikerjakan sebagai pemenuhan kehidupan sehari-hari yaitu sebagai petani dan berternak. Hal ini sesuai dengan kondisi alam tanah Sumba Timur yang secara geografis sebagian besar merupakan padang savana. Tempat/setting: tempat kejadian cerita dalam BI menceritakan kehidupan di Sumba Timur, sebuah wilayah di Nusa Tenggara Timur yang sebagian besar terdiri dari padang rumput dan lahan kering. Setting lainnya yaitu di wilayah Flores, yang merupakan salah satu daerah di Nusa Tenggara Timur yang terdiri dari daerah pesisir dan pegunungan. Konteks setting berupa bangunan asrama mencerminkan kehidupan calon pendeta/pastor di Sekolah Tinggi Filsafat Kristen Ledalero. Pendidikan/education; kehidupan calon imam atau pendeta di Sekolah Tinggi Filsafat Katolik di Ledalero, Flores. Agama/religion; nuansa Katolik yang sangat kentara, di dalamnya termanifestasi kehidupan pendeta dan calon pendeta Ledalero STFK, deskripsi bangunan, tahapan yang ditempuh oleh calon imam, tugas seorang imam dll. Penggunaan Bahasa/language use: selain bahasa Indonesia sebagai Bahasa utama yang digunakan dalam novel ini, Inyo Soro juga menceritakan kisahnya dengan sedikit bernuansa Melayu Kupang, Latin dan juga bahasa Inggris. Hal ini tak terelakkan mengingat bahwa seorang pendeta banyak berhubungan dengan literatur filosofis, liturgi, doa-doa yang dilantunkan menggunakan bahasa Latin. Bahasa Melayu adalah bahasa sosial yang digunakan oleh hamper semua kalangan masyarakat yang tinggal di wilayah Nusa Tenggara Timur dalam percakapan sosial ditengah-tengah berbagai bahasa daerah yang dimiliki oleh masing-masing wilayah atau suku-suka di Nusa Tenggara.

\section{SIMPULAN}

Simpulan yang bisa didapat dari novel Belis Imamat dan pandangan dunia penulis terhadap belis mencakup adat-istiadat dan kepercayaan, agama, bahasa, etnisitas, pekerjaan, pendidikan, dan tempat tinggal masyarakat Nusa Tenggara Timur 
sebagai penghantar tradisi yang diceritakan dalam BI. Dalam pandangan Inyo Soro, belis tak pelaknya memang sebuah tradisi yang mencerminkan tuntutan adat sebelum melangsungkan pernikahan yang dipersepsikan memberatkan, dan kerap mengikis nilai-nilai cinta dan kemanusiaan yang seharusnya menjadi tolok-ukur bagi hubungan pernikahan dua insan. Melalui BI kita bisa memahami bahwa novel ini muncul atas konsekuensi fenomena kehidupan budaya yang merupakan dokumentasi sosial. Ini adalah kritik sastra yang memungkinkan kita dalam menimbang dan memandang dimana posisi sebuah karya terhadap karya sastra lainnya mampu merangkum aspirasi masyarakat setempat terhadap budaya yang telah berlangsung lama dan terpelihara nampak tiada cela. Selain sebagai kritikan halus, kita pantas mendefinisikan novel ini sebagai semacam pembebasan, bukan alat yang mengikat apalagi melawan pola budaya yang sudah mapan. Meskipun kritik yang mengarah pada pembebasan akan membuat pencipta cerita menjadi lebih mampu menghasilkan kreasi mereka.

\section{DAFTAR PUSTAKA}

Balibar, Etienne.(2002). "Konfrontasi Michel Foucault dan Marx: Kritik terhadap Hipotesis Represi, Praksis, dan Struktur Konflik”, BASIS, No. 01-02, Year 51 ${ }^{\text {st }}$ January-February, p. 58-60.

Endraswara, Suwardi. (2008). Metodologi Penelitian Sastra [Trans. Method of Literary Studies]. Yogyakarta: MedPress.

Faucault, Michael. (1982).T he Subject and Power. Critical Inquiry, 8 (4) Summer, 1982, the Unviersity of Chicago Press. Retrieved from: http://www.jstor.org/page/info/about/policies/terms.jsp, pp.777-795

(al-) Lubab, Anas (15/08/2013). Ketika Pernikahan Dikuasai Adat dalam "Memang Jodoh". Retrieved from: http://www.alineatv.com/2013/08/15/ketika-pernikahan-dikuasai-adatdalam-memang-jodoh/ 
Moleong, Lexy. (2008). Metodologi Penelitian Kualitatif [Trans.Qualitative Research Methodology]. Bandung: Remaja Rosdakarya

Nurgiyantoro, Burhan.(2002). Teori Pengkajian Fiksi [Trans.Theory of Fiction Studies]. Yoyakarta: Gajah Mada University Press.

Siswantoro. (2005). Metode Penelitian Sastra: Analisis Psikologis. Surakarta: Muhammadiyah University Press.

Soekanto, Soedjono. (1996). Perkembangan Sosiologi. Yogyakarta: Tiara Wacana.

Stanton, Robert. (2007). Teori Fiksi [Trans. by Sugihastutik dan Rossi Abi AlIrsyad, "the theory of fiction"]. Yogyakarta: Pustaka Pelajar.

Sugiarto, Eko. (2007) .Melayu di mata Soeman Hs kritik terhadap adat lewat sebuah novel kritik terhadap adat lewat sebuah novel. Yogyakarta Balai Kajian dan Pengembangan Budaya Melayu 2007. ID: IOS3318YOGYA-02090000068720

Sumardjo, Jacob. (1999). Konteks Sosial Novel Indonesia 1920-1977. Bandung.

Sutiyono. (2010). Benturan Budaya Islam: Puritan dan Sinkretis. Jakarta: Kompas.

Wellek, R., \&Warren, A. (1989). Theory of Literature. New York: Harcourt. Brance and World 